\title{
FORMATION AND DESTRUCTION OF MICROBIAL BIOMASS DURING THE DECOMPOSITION OF GLUCOSE AND RYEGRASS IN SOIL
}

\author{
J. Wu, ${ }^{*}$ P. C. BRookes $\dagger$ and D. S. JENKINSON \\ Soil Science Department, AFRC Institute of Arable Crops Research, Rothamsted Experimental Station, \\ Harpenden, Herts AL5 2JQ, U.K,
}

(Accepted 15 March 1993)

\begin{abstract}
Summary $-{ }^{14} \mathrm{C}$-labelled glucose or ryegrass was incubated (aerobically, at $25^{\circ} \mathrm{C}$; each substrate added at either 500 or $5000 \mu \mathrm{g} \mathrm{C} \mathrm{g}^{-1}$ soil) with soil from permanent grassland. Soil microbial biomass was measured periodically during the incubation by the fumigation-extraction method. A 20 day incubation with the large addition of glucose $(5000 \mu \mathrm{g} \mathrm{C})$ caused the 'native' (i.e. unlabelled) microbial biomass to fall by half. The large addition of glucose caused a short-lived but marked priming effect and the size of this effect was consistent with its having been caused by a glucose-induced kill of native microbial biomass. Glucose added at $500 \mu \mathrm{g} \mathrm{C}$ did not cause a measurable kill of native microbial biomass, nor did it cause a priming effect. The proportion of glucose $\mathrm{C}$ retained in soil was greater throughout the incubation for the small $(500 \mu \mathrm{g})$ than for the large $(5000 \mu \mathrm{g})$ addition: likewise a greater proportion of the small addition was present in soil microbial biomass C (after 20 days, $21 \%$ of the added C) than of the large addition $(13 \%)$. The labelled biomass declined over the 5-10 day period, with a half-life of 60 days.

By contrast, labelled ryegrass added at $5000 \mu \mathrm{g} \mathrm{C}$ had little effect on the native microbial biomass, with the newly-synthesized labelled biomass merely adding to that already present. By 40 days, $12 \%$ of this ryegrass $\mathrm{C}$ was present as labelled microbial biomass, which then declined with a half-life of 66 days. After 30 days the proportion of labelled ryegrass $C$ retained in soil was greater with the small than with the large addition. Again, a greater proportion of the small addition was present in soil microbial $\mathrm{C}$ (after 20 days $19 \%$ of the added C) than of the large addition $(12 \%)$. Both the 500 and $5000 \mu \mathrm{g}$ additions of ryegrass $C$ caused positive priming effects over the $10-100$ day period.
\end{abstract}

\section{INTRODUCTION}

Sorensen (1974) and Dalenberg and Jager (1981) showed that the addition of unlabelled glucose to a ${ }^{14} \mathrm{C}$-labelled soil caused a small but significant increase in the evolution of labelled $\mathrm{CO}_{2}$. Dalenberg and Jager postulated that this 'priming effect' was caused by an enhanced turnover of $\mathrm{C}$ in the microbial biomass, not by enhanced decomposition of labelled humified organic matter. In later work (1989) with a range of substrates (glutamate, aspartate, cellulose, wheat straw and sewage sludge) they again observed 'priming effects' but these effects lasted longer than those following addition of glucose, and could not be exclusively attributed to changes in the microbial biomass.

The development of the fumigation-extraction technique for measuring soil microbial biomass permits its determination in soils containing activelydecomposing substrates (Ocio and Brookes, 1990; Brookes et al., 1990). We have used the new technique to monitor changes in microbial biomass during the decomposition of two uniformly ${ }^{14} \mathrm{C}$ labelled substrates (glucose and ryegrass) in soil. Our

*Present address: Faculty of Agriculture and Biological Sciences, University of Newcastle, Newcastle-upon-Tyne NE1 7RU, U.K.

+Author for correspondence. aim was to see how substrate affected the biomass already present in the soil when the substrate was added.

\section{MATERIALS AND METHODS}

\section{Incubation conditions}

The soil was a silty clay loam (Batcombe Series) from the permanent grassland plot of the Highfield ley-arable experiment (Johnston, 1973). Cores $(0-10 \mathrm{~cm}$ depth, $5 \mathrm{~cm}$ dia) were bulked in the field, hand-picked to remove discreet plant residues and visible soil fauna, then sieved moist $(<2 \mathrm{~mm})$. The moisture content of the soil was adjusted to $40 \%$ of water holding capacity (WHC) and it was then incubated at $25^{\circ} \mathrm{C}$ for 10 days before use. The soil contained $4.09 \%$ organic $\mathrm{C}, 0.397 \%$ total $\mathrm{N}$ and $24 \%$ clay and had a pH of 5.2; the WHC was $0.9 \mathrm{~g} \mathrm{H}_{2} \mathrm{O}$ $\mathrm{g}^{-1}$ soil. Its microbial biomass content at the start of the incubation was $890 \mu \mathrm{g}$ biomass $\mathrm{C}^{-1}$ soil.

Following the preliminary incubation, either uniformly ${ }^{14} \mathrm{C}$-labelled glucose (Sigma) or uniformly ${ }^{14} \mathrm{C}$-labelled ryegrass tops were added to portions of moist soil, each containing $25 \mathrm{~g}$ soil on an oven-dry basis, previously weighed into $60 \mathrm{ml}$ glass jars. The production of this labelled ryegrass, and its analysis for uniformity, have been described (Jenkinson, 1960: note that the material used in the present paper was 
that grown in "run B" of the 1960 paper). The glucose and ryegrass additions had specific activities

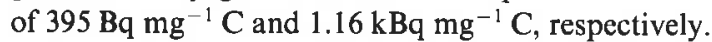
Both substrates were added at two rates: $5000 \mu \mathrm{g} \mathrm{C}$ $\mathrm{g}^{-1}$ soil ('large') and $500 \mu \mathrm{g} \mathrm{C}^{-1}$ soil ('small'); i.e. at 5.6 and 0.56 times the $C$ content of the 'native' soil microbial biomass, respectively.

The glucose was added to the soil in scattered $100 \mu \mathrm{l}$ aliquots, without mixing, using a speed-controlled syringe, containing $2 \mathrm{ml}$ solution. This solution also contained sufficient $\left(\mathrm{NH}_{4}\right)_{2} \mathrm{SO}_{4}$ to give a final $\mathrm{C}: \mathrm{N}$ ratio of 15 in the added substrate. The ryegrass, which had been stored in the freeze-dried state at $-15^{\circ} \mathrm{C}$ since it had been grown, was then oven-dried at $35^{\circ} \mathrm{C}$, finely ground $(<160 \mu \mathrm{m})$ and mixed with the moist soil: it contained $41.8 \%$ C. $2 \mathrm{ml}$ of a solution containing sufficient $\left(\mathrm{NH}_{4}\right)_{2} \mathrm{SO}_{4}$ to bring the $\mathrm{C}: \mathrm{N}$ ratio to about 15 was then added, as above. Control soils each received $2 \mathrm{ml}$ water.

Following these additions, where appropriate, each jar of soil was placed separately in a 1.1-litre stoppered glass jar containing $10 \mathrm{ml}$ free water and a $50 \mathrm{ml}$ vial containing $20 \mathrm{ml} 1 \mathrm{M} \mathrm{NaOH}$. The glucoseamended soils were incubated for 100 days and the ryegrass amended soils for 145 days, both in the dark at $25^{\circ} \mathrm{C}$. Biomass $\mathrm{C}$ and $\mathrm{CO}_{2}-\mathrm{C}$ evolved were measured periodically during these incubations. All incubations were done in triplicate.

\section{Analytical procedures}

Total $\mathrm{CO}_{2}-\mathrm{C}$ trapped in $1 \mathrm{M} \mathrm{NaOH}$ was measured by back-titration of $5 \mathrm{ml}$ aliquots of $1 \mathrm{M} \mathrm{NaOH}$ with $0.7 \mathrm{M} \mathrm{HCl}$, using an autotitrator, and measuring the volume of $\mathrm{HCl}$ consumed between $\mathrm{pH} 8.3$ and 3.7 . ${ }^{14} \mathrm{C}$-labelled $\mathrm{CO}_{2}\left({ }^{14} \mathrm{CO}_{2}\right)$ trapped in $1 \mathrm{M} \mathrm{NaOH}$ was measured by adding $2 \mathrm{ml} \mathrm{NaOH}$ to $10 \mathrm{ml} \mathrm{RIA}^{\mathrm{lm}}$ scintillation cocktail (Fisons plc) and counting for 5 min in a Beta Matic scintillation counter.

Biomass $\mathrm{C}$ was measured by fumigation-extraction (Vance et al., 1987; Wu et al., 1990). Total biomass C $\left(B_{\mathrm{C}}\right)$ was calculated from $B_{\mathrm{C}}=2.22 E_{\mathrm{C}}$ where: $E_{\mathrm{C}}=$ (organic $\mathrm{C}$ extracted by $0.5 \mathrm{M} \quad \mathrm{K}_{2} \mathrm{SO}_{4}$ from fumigated soil) minus (organic $\mathrm{C}$ extracted from non-fumigated soil).

${ }^{14} \mathrm{C}$-labelled organic $\mathrm{C}$ extracted by $0.5 \mathrm{M} \mathrm{K}_{2} \mathrm{SO}_{4}$ was measured by mixing $1 \mathrm{ml}$ aliquots of the $\mathrm{K}_{2} \mathrm{SO}_{4}$ extract with $15 \mathrm{ml}$ RIA scintillant and $2 \mathrm{ml}$ water, and counting the mixture by liquid scintillation as above. Amounts of ${ }^{14} \mathrm{C}$-labelled biomass $\mathrm{C}$ (biomass ${ }^{14} \mathrm{C}$ ) were calculated from: biomass ${ }^{14} \mathrm{C}=2.22 E_{14 \mathrm{C}}$, where $E_{14 \mathrm{C}}$ is measured and calculated as above.

The quantity of ${ }^{14} \mathrm{C}$ remaining in the soil at the end of these experiments was not measured, so an overall ${ }^{14} \mathrm{C}$ balance could not be drawn up. However, incubations carried out under the same conditions and using identical soil and analytical procedures to those used here (Jinshui Wu-unpublished), gave satisfactory balances. Thus $101 \%$ of the original ${ }^{14} \mathrm{C}$ added in glucose was either trapped in alkali or remained in the soil at the end of a 100 day incubation. For uniformly ${ }^{14} \mathrm{C}$-labelled wheat straw, the corresponding value was $95 \%$ at 120 days of incubation.

\section{RESULTS}

\section{Decomposition of glucose and ryegrass}

The evolution of ${ }^{14} \mathrm{CO}_{2}$ during the decomposition of glucose and ryegrass followed the usual pattern: initially the glucose decomposed much more rapidly than the ryegrass but by 100 days the ryegrass had almost caught up (Fig. 1). Throughout the incubation, the proportion of the added glucose $\mathrm{C}$

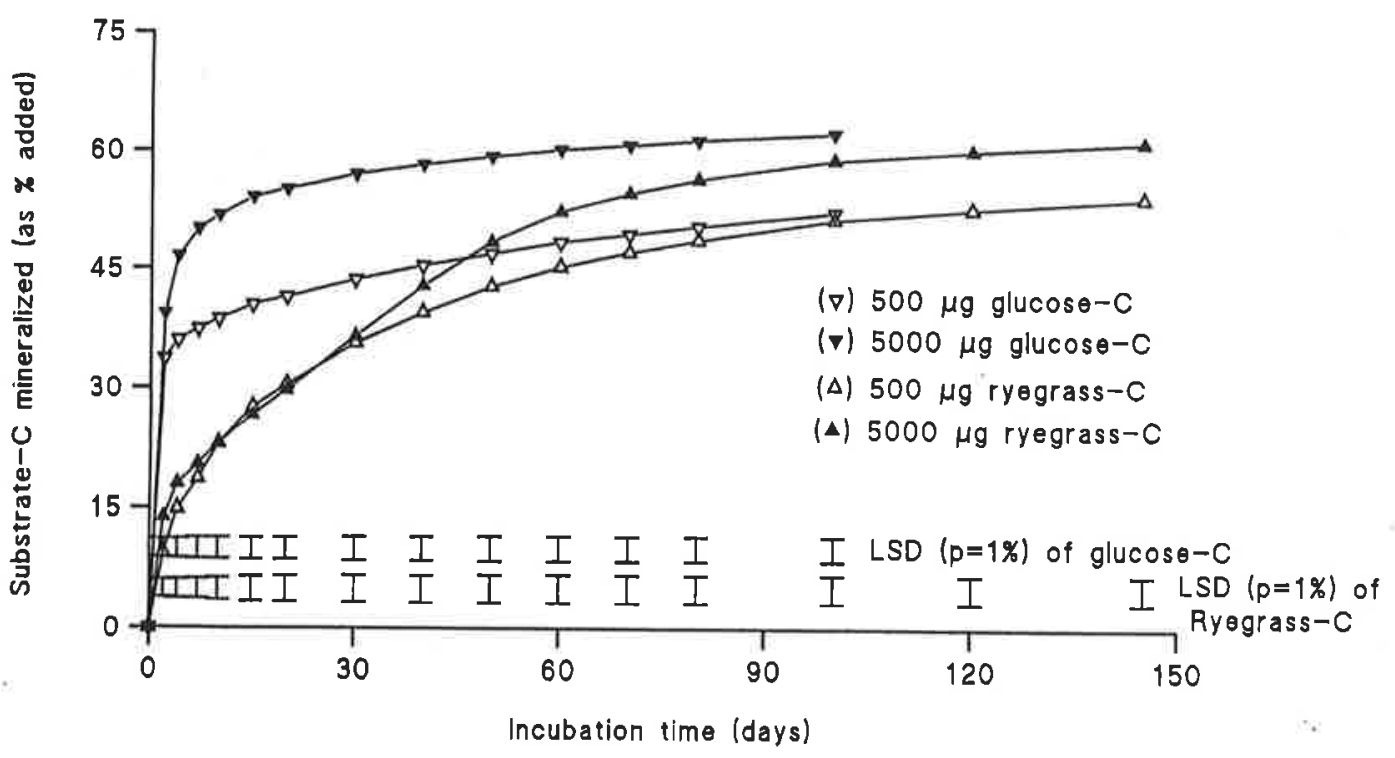

Fig. 1. Mineralization of ${ }^{14} \mathrm{C}$-labelled glucose and ryegrass in the Highfield grassland soil, each added at either 500 or $5000 \mu \mathrm{g} \mathrm{C}^{-1}$ soil. 


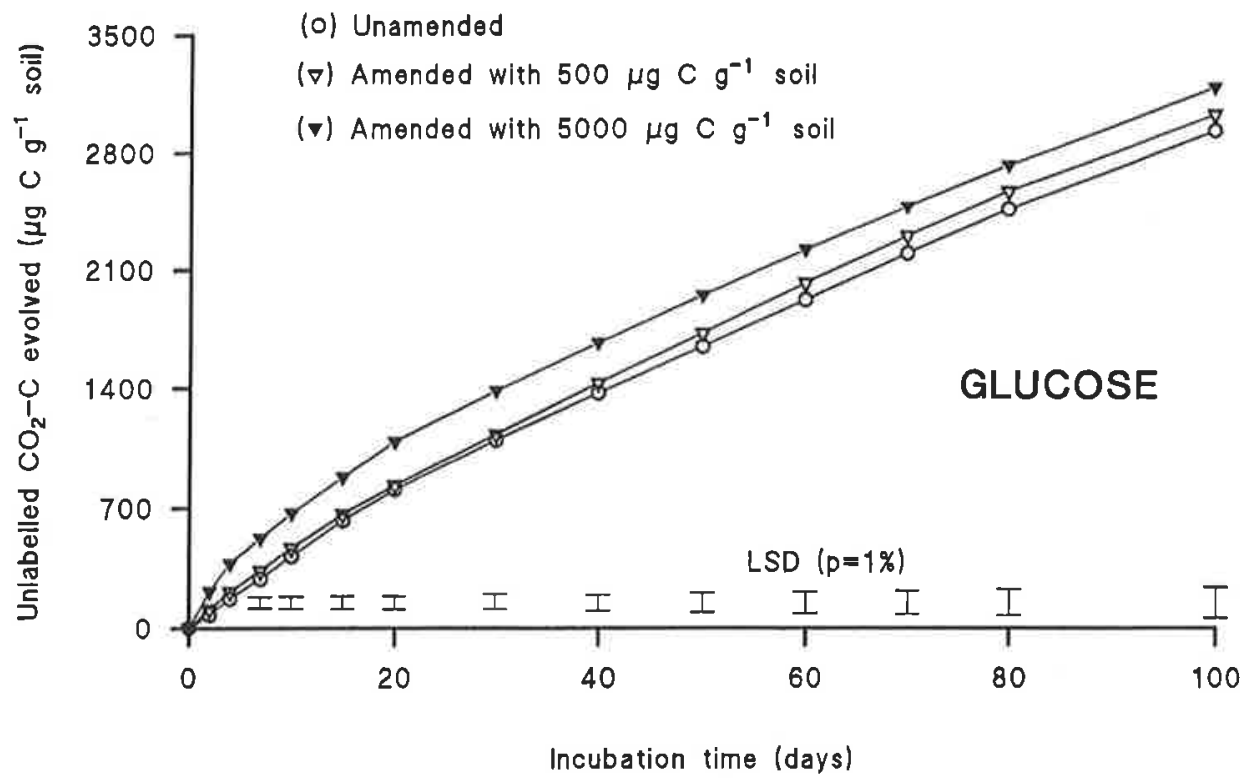

Fig. 2. Mineralization of native soil organic $\mathrm{C}$ in the Highfield grassland soil, incubated either alone, with 500 or with $5000 \mu \mathrm{g}$ glucose- $\mathrm{C} \mathrm{g}^{-1}$ soil.

retained in the soil was greater with the small than with the large addition; with ryegrass the proportion retained by the small addition only became greater after 30 days.

The large additions of both substrates produced a 'priming effect' (Figs 2 and 3). The large addition of glucose caused a significant increase in evolution of unlabelled $\mathrm{CO}_{2}-\mathrm{C}$, reaching a maximum at about day 10 , by which time the amended soil had evolved about $60 \%$ more $\mathrm{CO}_{2}-\mathrm{C}$ than the control. Thereafter the rates of unlabelled $\mathrm{CO}_{2}-\mathrm{C}$ evolution from the glucose amended and control soils were very similar. Overall, the addition of glucose produced about $300 \mu \mathrm{g} \mathrm{g}^{-1}$ soil of extra unlabelled $\mathrm{CO}_{2}-\mathrm{C}$, an increase of $10 \%$ over that evolved by the control in 100 days. The smaller addition of glucose caused hardly any priming effect.

The pattern of evolution of unlabelled $\mathrm{CO}_{2}-\mathrm{C}$ from the soil amended with ryegrass was very different from that with glucose. Unlike with glucose, the rate

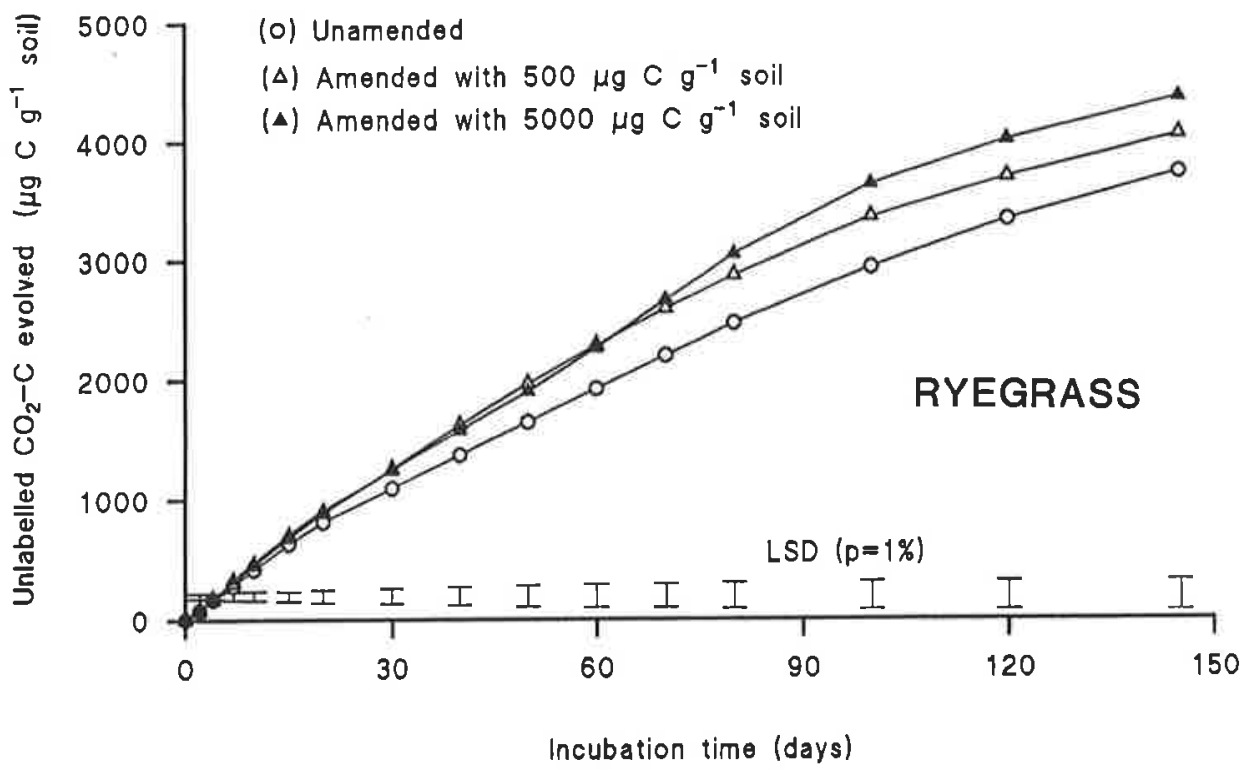

Fig. 3. Mineralization of native soil organic $C$ in the Highfield grassland soil, incubated either alone, with 500 or with $5000 \mu \mathrm{g}$ ryegrass- $\mathrm{C} \mathrm{g}^{-1}$ soil. 


\section{GLUCOSE}

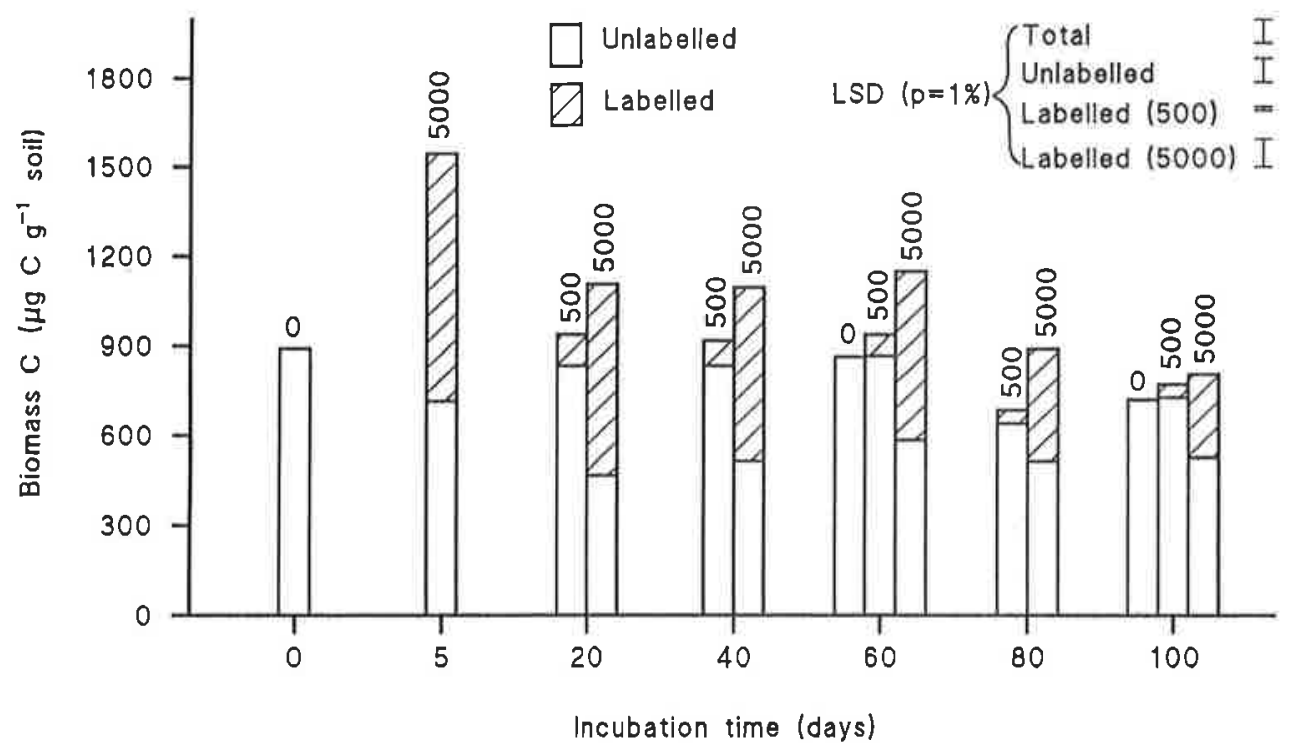

Fig. 4. Changes in total, labelled and unlabelled biomass $\mathrm{C}$ in the Highfield grassland soil, incubated either alone, with 500 or with $5000 \mu \mathrm{g}$ glucose-C $\mathrm{g}^{-1}$ soil.

of evolution of unlabelled $\mathrm{CO}_{2}$ was only slightly faster over the first 30 days in the ryegrass-amended soil than in the unamended control soil (Fig. 3). Thereafter the gap widened slowly, until about day 60 , when the rate of separation increased markedly for a time. By 100 days the large addition caused a priming effect of about $700 \mu \mathrm{g} \mathrm{g}^{-1}$ soil of extra unlabelled $\mathrm{CO}_{2}-\mathrm{C}$, about twice that caused by the large addition of glucose. The small addition of ryegrass caused about half the priming effect of the large. Priming effects in the ryegrass-amended soils were effectively over after 100 days.

\section{Changes in soil biomass $C$ contents following addition of glucose or ryegrass}

The biomass declined very slowly in unamended soil: by 100 days it had fallen to about $80 \%$ of its initial value (Fig. 4). Consider first the large addition of glucose. This caused the total biomass to almost double by day 5 , from about 900 to $1550 \mu \mathrm{g} \mathrm{C} \mathrm{g}^{-1}$ soil (Fig. 4). However, the large increased population was not sustained and by day 20 the amount of total biomass $C$ was only $24 \%$ greater than that in the unamended soil at the beginning of the incubation. From about 20 to 60 days, the amount of total biomass $\mathrm{C}$ changed little, with a further decline of about $30 \%$ between 60 and 100 days (Fig. 4). The large glucose addition caused a considerable decline in the native, unlabelled biomass. By day 5 it had fallen by a quarter, by day 20 by almost half. Thereafter it changed little, although there is a suggestion of a slow recovery (Fig. 4). As a consequence of these changes, the proportion of the biomass that was labelled changed markedly during incubation: at day 5 about $54 \%$ of the total biomass was labelled, by day 100 only $35 \%$. Labelled biomass declined steadily from day 5 , when it was first measured, with a crude (i.e. uncorrected for $\mathrm{C}$ recycling) half-life of 60 days over the 5-100 day period.

Figure 4 shows that the main effects of the large glucose addition on the native unlabelled population occurred during the first 20 days following glucose addition, i.e. at the time that the priming effect occurred. The decline in unlabelled biomass $\mathrm{C}$ during the first 20 days of incubation with glucose was about $420 \mu \mathrm{g} \mathrm{g}^{-1}$ soil; the cumulative priming effect by day 20 was $280 \mathrm{mg} \mathrm{CO}-\mathrm{C}$ (Fig. 2).

Now consider the effects of the small glucose addition. Here there was no detectable kill and no significant priming effect. Throughout the incubation the percentage of glucose $C$ remaining in biomass was higher with the small addition than the large: thus after 20 days $21 \%$ of the small glucose $\mathrm{C}$ addition was in the biomass, $13 \%$ of the large.

The effects of the large addition of ryegrass on soil microbial biomass (Fig. 5) were very different to those of glucose. Firstly, the increase in total biomass, measured at 20, 40 and 60 days, was larger than that following glucose. More importantly, there was very little, if any, replacement of the original biomass with a ${ }^{14} \mathrm{C}$-labelled biomass derived from the ryegrass. Instead, the ${ }^{14} \mathrm{C}$-labelled biomass simply added to the total biomass pool. Although the labelled biomass changed little between 20 and 40 days, it then started to decline at much the same rate (with a crude half-life of 66 days over the 40-145 day period), as did the labelled biomass in the glucose experiment (half-life 60 days). 
The small addition of ryegrass did not cause any consistent replacement of the native biomass either. Again, as with glucose, more of the small addition than of the large was retained in biomass: after 20 days $19 \%$ of the small addition was in biomass, $13 \%$ of the large.

\section{DISCUSSION}

The salient feature of this work is the effect of glucose on the native (unlabelled) soil microbial biomass. It is as if large additions of glucose are toxic - eliminating half the native biomass by the end of 20 days. We do not know why glucose affects the biomass in this way. The glucose might bring a large part of the native biomass out of dormancy, only to perish when all the glucose is exhausted. This is tantamount to a transient increase in the death rate of the native biomass. Another possibility is the killing of organisms by osmotic shock, although the soil solution glucose concentration was only $0.16 \mathrm{M}$ even with the large addition. If we assume that $0.16 \mathrm{M}$ glucose kills half the soil microbial biomass by osmotic shock, this kill must occur right at the beginning of the incubation, when the glucose concentration was at its maximum. Figure 4 shows that most loss of native biomass occurs between 4 and 20 days, not during the initial 5 days.

The decline in the size of the native biomass caused by the large glucose addition is almost exactly matched by the size of the priming effect. If we assume (1) that $45 \%$ of the $C$ in a killed population of soil organisms is mineralized to $\mathrm{CO}_{2}$ at $25^{\circ} \mathrm{C}$ in the 10 days following death (Jenkinson, 1988), (2) that a further $5 \%$ is mineralized in the succeeding 10 days, and (3) that all the killing occurred at the beginning of the incubation, then the $420 \mu \mathrm{g}$ of native biomass $\mathrm{C}$ that disappeared by day 20 should have released $240 \mu \mathrm{g} \mathrm{CO}_{2}-\mathrm{C}$ by the end of the first 20 days. This is not very different from the $280 \mu \mathrm{g} \mathrm{CO}_{2}-\mathrm{C}$ released by priming (Fig. 2). The discrepancy will become a little greater if assumption (3) is relaxed and the time of death is not confined to the first day, as indeed the results suggest (Fig. 4). This is strong evidence that the priming caused by the large addition of glucose in these experiments is due to the accelerated death of about half the microbial biomass that was already present when the glucose was added.

Neither large nor small ryegrass additions cause any significant change in the size of the native unlabelled biomass, over and above the normal slow decline observed whether substrate is present or not. We do not know why ryegrass differs from glucose in this way. The relatively insoluble ryegrass, although carefully mixed with the soil, will be in direct contact with considerably fewer of the 'native' organisms than the water-soluble glucose, and so presumably less able to influence them. Another explanation is that glucose can be used as a substrate by the vast majority of soil organisms (Anderson and Domsch, 1978), whereas many ryegrass constituents; lignins, hemicellulose and cellulose in particular, require specialized organisms for their decomposition. Such specialized organisms could reasonably be expected

\section{RYEGRASS}

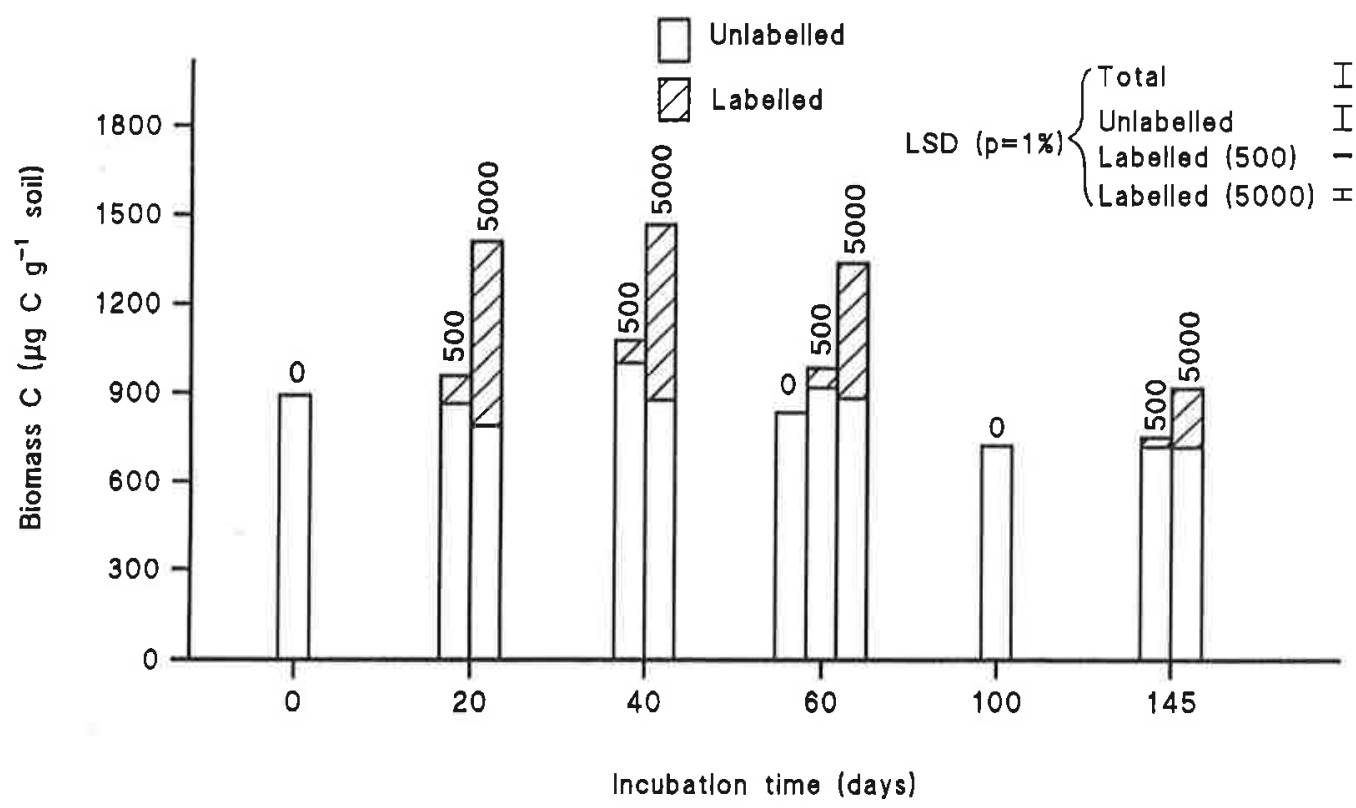

Fig. 5. Changes in total, labelled and unlabelled biomass $\mathrm{C}$ in the Highfield grassland soil, incubated either alone, with 500 or with $5000 \mu \mathrm{g}$ ryegrass- $\mathrm{C} \mathrm{g}^{-1}$ soil. 
to form an insignificant part of the whole soil microbial biomass.

Our observation that large additions of glucose are more completely converted to $\mathrm{CO}_{2}$ than small, throughout the whole course of these incubations, is in accord with the work by Bremer and Van Kessel (1990), who put forward a number of explanations for this result. However it should be noted that our estimates of the proportion of added glucose $\mathbf{C}$ converted to microbial biomass are consistently much lower than those of either Bremer and Van Kessel or Gregorich et al. (1991). Both groups used a fumigation-extraction procedure similar to ours for measuring microbial biomass in soils incubated with ${ }^{14} \mathrm{C}$-labelled glucose. The reason for the discrepancy is not that the measurements themselves were very different but that the factor we used to convert $\mathrm{K}_{2} \mathrm{SO}_{4}$ extractable ${ }^{14} \mathrm{C}$ released by fumigation $\left(E_{14_{\mathrm{C}}}\right)$ to soil microbial biomass was much smaller than the proportionality factor they used, based on their assumption that all of the glucose $\mathrm{C}$ present after 1 day (apart from the glucose $\mathrm{C}$ evolved as $\mathrm{CO}_{2}$ ) resides in the biomass.

Whereas the priming effect caused by large additions of glucose can be satisfactorily explained by changes in the size of the native biomass, as originally proposed by Dalenberg and Jager (1981), the priming effect caused by ryegrass cannot. With large and small additions of ryegrass, the priming effect manifested itself mainly over the $10-100$ day period, exactly when the ryegrass incubations were evolving ${ }^{14} \mathrm{CO}_{2}$ more rapidly than the glucose incubations. A possible explanation is that the ligninases and cellulases produced by the organisms degrading the ryegrass are also capable of decomposing some of the native soil organic matter-indeed this is the original explanation of the priming effect. However the large addition of ryegrass produced roughly 7 times as much biomass $C$ as the small one over the whole incubation period, yet the priming effect was only twice as big. This suggests that the production of ligninases and celluases is not linearly related to the increase in biomass, or, alternatively, that our soil contains only a very limited quantity of susceptible native soil organic matter, a quantity moreover that does not include the 'native' microbial biomass.

There are numerous problems in measuring the priming effect, particularly in prolonged incubations with substrates that are not perfectly uniformly labelled (see Jenkinson, 1966, 1971 and Sauerbeck, 1966, for an examination of the pitfalls) and our results with ryegrass, although indicative of a positive priming action over the 10-100 day period, should not be pushed too far.

By the end of the incubations, the soils that had received substrate contained little more biomass than those that had not, in accord with Nannipieri et al.'s (1983) earlier observation. Although Nannipieri et al. suggested that this comes about because each soil contains only a limited number of sites able to give protection to a living organism, it is perhaps more likely that this 'background' biomass appears to be unchanging because it is living on and continually being created from the enormous (and relatively constant) stock of humified soil organic carbon.

Acknowledgements - J. Wu thanks Academia Sinica and Changsha Institute of Agricultural Modernization for their support during his time at Rothamsted Experimental Station.

\section{REFERENCES}

Anderson J. P. E. and Domsch K. H. (1978) A physiological method for the quantitative measurement of microbial biomass in soils. Soil Biology \& Biochemistry 10, 215-221.

Bremer E. and Van Kessel C. (1990) Extractability of microbial ${ }^{14} \mathrm{C}$ and ${ }^{15} \mathrm{~N}$ following addition of variable rates of labelled glucose and $\left(\mathrm{NH}_{4}\right)_{2} \mathrm{SO}_{4}$ to soil. Soil Biology \& Biochemistry 22, 707-713.

Brookes P. C., Ocio J. A. and Wu J. (1990) The soil microbial biomass: its measurement, properties and role in soil nitrogen and carbon dynamics following substrate incorporation. Soil Microorganisms $35,39-51$.

Dalenberg J. W. and Jager G. (1981) Priming effect of small glucose additions to ${ }^{14} \mathrm{C}$-labelled soil. Soil Biology \& Biochemistry 13, 219-223.

Dalenberg J. W. and Jager G. (1989) Priming effects of some organic additions to ${ }^{14} \mathrm{C}$-labelled soil. Soil Biology \& Biochemistry 21, 443-448.

Gregorich E. G., Voroney R. P. and Kachanoski R. G. (1991) Turnover of carbon through the microbial biomass in soils with different textures. Soil Biology \& Biochemistry 23, 799-805.

Jenkinson D. S. (1960) The production of ryegrass labelled with ${ }^{14}$ C. Plant \& Soil 13, 279-290.

Jenkinson D. S. (1966) The priming effect. In Use of Isotopes in Soil Organic Matter Studies, pp. 199-208. Report for FAO/IAEA Technical Meeting. Brunswick, Volkenrode, 1963. Pergamon Press, Oxford.

Jenkinson D. S. (1971) Studies on the decomposition of ${ }^{14} \mathrm{C}$-labelled organic matter in soil. Soil Science 111, 64-70.

Jenkinson D. S. (1988) The determination of microbial biomass carbon and nitrogen in soil. In Advances in Nitrogen Cycling in Agricultural Ecosystems (J. R. Wilson, Ed.), pp. 368-386, CAB, Wallingford.

Johnston A. E. (1973) The effects of ley and arable cropping systems on the amounts of soil organic matter in the Rothamsted and Woburn ley-arable experiments. Rothamsted Experimental Station Report for 1972 (Part 2), pp, 131-159.

Nannipieri P., Muccini L. and Ciardi C. (1983) Microbial biomass and enzyme activities: production and persistence. Soil Biology \& Biochemistry 15, 679-685.

Ocio J. A. and Brookes P. C. (1990) An evaluation of methods for measuring the soil microbial biomass in soils following recent additions of wheat straw and the characterization of the biomass that develops. Soil Biology \& Biochemistry 22, 685-694.

Sauerbeck D. (1966) A critical evaluation of incubation experiments on the priming effect of green manure. In Use of Isotopes in Soil Organic Matter Studies, pp. 209-221. Report for FAO/IAEA Technical Meeting. Brunswick, Volkenrode, 1963. Pergamon Press, Oxford. 
Sorensen L. H. (1974) Rate of decomposition of organic matter in soil as influenced by repeated airdrying-rewetting and repeated additions of organic matter. Soil Biology \& Biochemistry 6, 287-292.

Vance E. D., Brookes P. C. and Jenkinson D. S. (1987) An extraction method for measuring soil microbial biomass. Soil Biology \& Biochemistry 19, 703-707.

Wu J., Joergensen R. G., Pommerening B., Chaussod R. and Brookes P. C. (1990) Measurement of soil microbial biomass $\mathrm{C}$ by fumigation-extraction - an automated procedure. Soil Biology \& Biochemistry 22, 1167-1169. 
